\title{
Interaction of physical activity and diet: implications for haemostatic factors
}

\author{
Rainer Rauramaa* and SB Väisänen \\ *Kuopio Research Institute of Exercise Medicine, Haapaniementie 16 FIN-70100 Kuopio, Finland
}

Accepted: 11 June 1999

\begin{abstract}
Regular moderate intensity physical activity and habitual diet providing no more than one third of energy from fats have been recommended for the prevention of atherosclerotic diseases. The background for these guidelines is the key role of plasma lipids. However, the importance of thrombogenesis in acute myocardial infarction has become obvious during the last decade. Hyperlipidaemia and excess of adipose tissue increase platelet aggregability and blood coagulation, and decrease fibrinolysis. Both regular physical activity and dietary fat reduction decrease blood lipids and body fat thereby diminishing the risk of thrombosis. Currently, data on interactions between physical activity and diet on haemostasis are scarce, and the few studies available have not demonstrated additional effects when these two lifestyle modifications have been combined. This paper is restricted only to studies using controlled randomized design. Regular moderate intensity physical activity as well as diet rich in omega-3 fatty acids decrease platelet aggregability. The effects of regular physical activity on plasma fibrinogen remain contradictory, while the impact of diet is even less clear. Plasminogen activator inhibitor-1, a possible link between insulin resistance syndrome and coronary heart disease, may decrease due to physical training or low fat diet. It can be hypothesized that moderation in physical activity and diet carries a more powerful impact on blood coagulation and fibrinolysis than either lifestyle modification alone. Studies focusing on the interactions of regular moderate physical activity and fat-modified diet are needed in efforts to optimize the preventive actions by lifestyle changes.
\end{abstract}

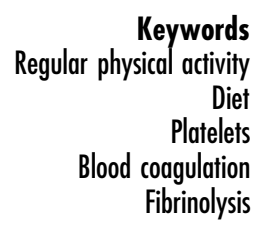

\section{Key research topics}

The following research topics are suggested for future clinical trials.

- Effects of regular mild to moderate intensity physical activity combined with low fat (30 E\%) high carbohydrate diet on thrombogenesis involved in atherosclerosis with special reference to body composition.

- Effects of regular mild to moderate intensity physical activity combined with low fat $(30 \mathrm{E} \%)$ high carbohydrate diet on thrombogenic profile in postmenopausal women.

- Effects of regular physical activity of different intensities combined with low fat (30 E\%) high carbohydrate diet on haemostatic factors with special references to genetic variations in thrombogenic factors.

\section{Introduction}

The essential role that haemostatic factors play in the clinical events of atherosclerosis has been understood only recently. Nowadays, it is well recognized that atherosclerosis is a chronic inflammatory condition ${ }^{1}$, which turns into an acute clinical event as a consequence of plaque rupture with the ensuing thrombosis. The progression of an atherosclerotic lesion from a fatty streak to an atherosclerotic plaque is to a large extent dependent on the circulating level of low density lipoprotein cholesterol as well as other atherogenic lipoproteins and their susceptibility for oxidative modification. In the event of plaque rupture, the elements of circulating blood are exposed to tissue factor, the initiator of thrombosis ${ }^{2}$. While moderation in both physical activity level and dietary fat intake have been shown to be effective in modifying the blood levels of atherogenic factors, very little data are available on the interactions of moderate regular exercise and diet on the haemostatic factors.

\section{Haemostasis}

Vascular haemostasis results from a regulated interaction of blood coagulation and fibrinolysis. In a normal situation these systems are in dynamic equilibrium, but 
any imbalance between them leads to a tendency to bleeding or to an increased thrombogenesis ${ }^{2}$. Platelets provide the key elements to haemostasis. They adhere to the damaged endothelium of vessel walls and to each other to form aggregates thereby stopping blood from leaving the vascular compartment. After reacting with foreign surfaces, platelets become activated and change their shape to irregular spheres by putting out pseudopods. These activated platelets adhere to the vessel wall and to each other to form aggregates. Blood coagulation is initiated by at least two different mechanisms (Fig. 1). The slower activation process of fibrin formation by the intrinsic mechanism is dependent on circulating coagulation factors. The more rapid activation process of the extrinsic system needs an extravascular factor, tissue factor, to initiate the coagulation process $^{3}$. Factor VII (FVII) has a key role in the initiation of the extrinsic coagulation pathway by forming a complex with the tissue factor. Fibrinogen plays a central role in the final phase of the blood coagulation cascade, and the binding of fibrinogen to platelet glycoprotein IIb/IIIa receptors is the principal mechanism for platelet aggregation ${ }^{4}$.

The fibrinolytic system regulates the formation and removal of thrombi and maintenance of vascular patency (Fig. 1). Plasminogen activators activate plasminogen to plasmin, which degrades fibrin into soluble fibrin degradation products. Activation of plasminogen to plasmin by tissue-type plasminogen activator (t-PA) is enhanced in the presence of fibrin or at the endothelial cell surface. Inhibition of fibrinolysis may occur at the level of plasminogen activation, plasminogen activator inhibitor type-1 (PAI-1) as the key inhibitor, or at the level of plasmin by $\alpha_{2-}$ antiplasmin $^{5}$. Increased PAI-1 and decreased t-PA levels lead to suppression of fibrinolytic activity and reduced plasmin generation favouring fibrin persistence and thrombosis ${ }^{6}$.

\section{BLOOD COAGULATION}

Thrombin, XIIa

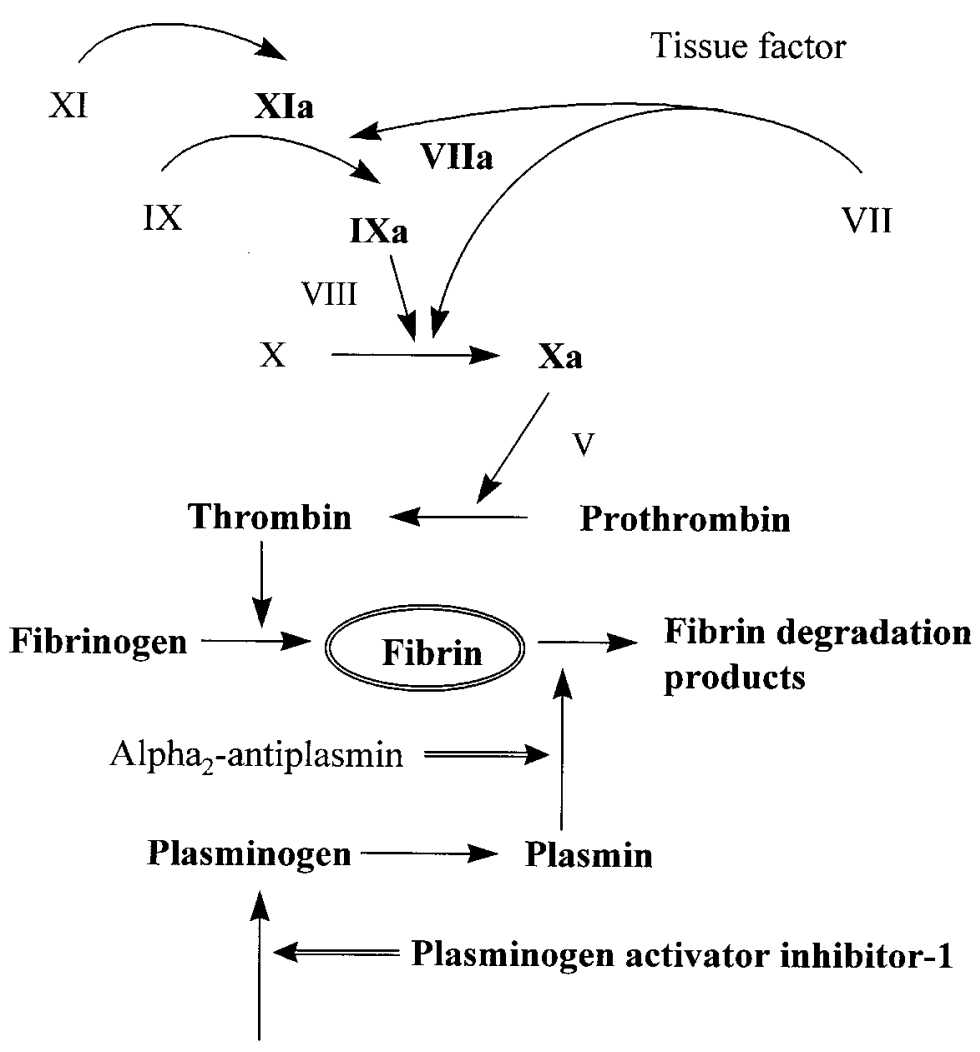

Tissue-type plasminogen activator

\section{FIBRINOLYSIS}

Fig. 1 A schematic presentation of factors participating in blood coagulation and fibrinolysis 


\section{Platelet aggregability}

Increased platelet aggregability during the morning hours has been linked to the circadian fluctuation of acute cardiac events ${ }^{7}$. Strenuous exercise activates platelets acutely, while exercise training at moderate intensity suppresses platelet aggregation in overweight middle-aged men ${ }^{8}$, in young healthy men ${ }^{9}$ as well as in young women ${ }^{10}$. Physical activity can induce at least two different mechanisms, which affect platelet function. Regular physical activity increases serum high density lipoproteins, which can stimulate prostacyclin production $^{11}$ and thereby decrease platelet aggregation. In addition, physical activity increases release of nitric oxide, a potent mediator of antiplatelet effects for instance by elevating cGMP content in platelets, which in turn suppresses platelet reactivity ${ }^{9}$. However, the resting and exercise-induced reductions in platelet aggregation reverse back to the pretraining level after deconditioning ${ }^{9,10}$ indicating the importance of engaging in physical activity in a regular manner. Of the dietary components, fish intake, and particularly high intake of eicosapentaenoic acid (EPA) increases bleeding time and decreases platelet aggregability ${ }^{12}$, and incorporating omega-3 fatty acids into a low rather than high fat diet appears to have especially beneficial effects on men at risk of $\mathrm{CHD}^{13}$.

\section{Coagulation Factor VII}

A positive association between increased factor VII coagulant activity (FVIIc) and risk of ischemic heart disease, especially for fatal events, was initially shown in the Northwick Park Heart Study ${ }^{14}$. Only few reports on the effects of physical exercise on FVII are available, and it seems that at least moderate exercise has no significant influence on FVII level ${ }^{15-17}$ or the effect is at the most only relatively short-lived ${ }^{18}$. Dietary fat intake associates positively with FVIIc both in the fasting and postprandial states ${ }^{19-25}$. Blood lipids may have an essential role in the relationship between fat intake and FVII, since several cross-sectional and postprandial studies have shown a strong positive relation of triglyceride-rich lipoproteins to FVIIc or FVII antigen level (FVIIag) ${ }^{21,24,26,27}$.

In the DNASCO study (DNA Polymorphism and Atherosclerosis: Controlled Randomized Clinical Trial on the Effects of Regular Physical Activity), we found that in subjects with low apolipoprotein B (apo B) level, FVIIc was raised only when fat intake was high (>38 E\%), while FVIIc increased gradually with dietary fat in the middle apo B tertile. No association was seen in men with the highest serum apo B concentration. Dietary fat seems to be more important in the regulation of FVIIc in subjects with low to moderate serum apo B concentration than in those with higher apo B levels ${ }^{28}$. In dietary interventions, FVIIc decreased after a low fat diet (fat intake $26-28 \mathrm{E} \%$ ) $^{29,30}$, and also after a fat free meal containing only carbohydrates ${ }^{24}$. No difference in FVIIc was detected between two dietary periods, which differed moderately in fat content ( $39 \mathrm{E} \%$ vs. $31 \mathrm{E} \%)^{31}$, whereas FVIIc level was elevated after very high fat diets (62-63 E\%) compared to a very low fat diet $(<20$ $\mathrm{E} \%)^{32}$. Change in fat composition, when the total fat intake remained the same, had no effect on FVIIc in normolipidaemic subjects ${ }^{18}$, and FVIIc decreased similarly during low fat diets with different fatty acid compositions ${ }^{29}$.

Cross-sectional studies revealed a positive correlation of FVIIag ${ }^{26,33}$ and FVIIc ${ }^{20,26,28}$ with triglyceride level. However, the relationship between FVIIc and triglycerides is not so evident during dietary interventions ${ }^{19,25,29,34}$. When hypercholesterolaemic patients were treated with a lipid-lowering agent, FVIIag and FVIIc decreased concomitantly with the reduction in triglyceride level ${ }^{35}$. Despite severe hypertriglyceridaemia in the chylomicron and VLDL fractions, neither FVIIag nor FVIIc were elevated in patients with homozygous familial lipoprotein lipase (LPL) deficiency ${ }^{36}$ or in patients with myocardial infarction and decreased LPL activity ${ }^{27}$. These observations suggest that lipolysis of the large lipoprotein particles has an important influence on the in vivo activation of FVII.

Genetic polymorphisms in the FVII gene contribute significantly to the FVII level ${ }^{37-41}$. In Caucasians, an interaction between serum triglycerides and FVIIc was reported in subjects carrying the common ${ }^{353} \mathrm{Arg}$ allele, which associates with higher FVIIc ${ }^{38}$. However, Saha and coworkers ${ }^{39}$ reported an opposite relationship in Dravidian Indians, in whom homozygotes for the ${ }^{353} \mathrm{Arg}$ allele had a weaker relationship between triglycerides and FVIIc compared to the other genotypes. FVIIag responded to the oral fat load similarly in subjects homozygotes or heterozygotes for the ${ }^{353} \mathrm{Arg}$ allele ${ }^{41}$. Weight loss by dietary modifications and physical activity induced reductions in FVIIc similarly in the carriers of the ${ }^{353} \mathrm{Gln}$ allele and the homozygous for the ${ }^{353} \mathrm{Arg}$ in moderately obese subjects. However, the absolute reduction in FVIIc was greater in the ${ }^{353} \mathrm{Arg}$ homozygotes, who had initially higher FVIIc values ${ }^{42}$.

\section{Fibrinogen}

Fibrinogen is an independent risk factor for cardiovascular disease and mortality ${ }^{43,44}$ and the plasma level is elevated in inflammatory states, smokers, obesity, diabetes and hyperlipidaemia. Although an inverse relationship between fibrinogen and physical activity and/or cardiorespiratory fitness was found in several cross-sectional studies ${ }^{45}$, the fibrinogen lowering effect of regular physical activity was reported in only a few exercise intervention studies ie, in an uncontrolled study in old men ${ }^{46}$, in sedentary subjects with newly diagnosed $\mathrm{NIDDM}^{47}$, and after 10 weeks of strenuous 
Table 1 Summary table of the potential effects of regular physical exercise or diet (fat modified and/or energy restricted) on haemostatic factors in controlled randomized clinical trials

\begin{tabular}{lcc}
\hline & Physical exercise & Diet \\
\hline Platelet aggregability & $\Downarrow$ & $\Downarrow$ \\
Factor VII & no effect & $\Downarrow$ \\
Fibrinogen & $?$ & no effect \\
t-PA antigen & $\Downarrow$ & $\Downarrow$ \\
t-PA activity & $\Uparrow$ & no effect \\
PAl-1 antigen and activity & $\Downarrow$ & $\Downarrow$ \\
\hline
\end{tabular}

and intensive training in young men ${ }^{48}$. In contrast, moderate exercise did not change fibrinogen in overweight women ${ }^{49}$ and an intensive exercise program increased plasma fibrinogen in elderly subjects ${ }^{50}$.

Two recent studies have examined whether genetic polymorphisms in the fibrinogen genes can modulate the association between physical activity and plasma fibrinogen. We found an interaction between habitual physical activity and an $\alpha$-fibrinogen polymorphism on fibrinogen level in postmenopausal women. The physically most active women, who were homozygous for the more frequent Rsa I allele, displayed a decreased plasma fibrinogen, while the association was not seen in other genotypes ${ }^{51}$. An acute phase response in fibrinogen level was reported in young men after an exhausting 2-day military exercise period. The subjects carrying the A allele of the G-453-A polymorphism in the $\beta$-fibrinogen gene had higher increase in plasma fibrinogen than in men with the GG genotype ${ }^{48}$. Controlled exercise intervention studies are needed to further evaluate the effect of genetic variation at the fibrinogen gene loci on the relationship between physical activity and fibrinogen level in both genders.

As to the impact of diet on fibrinogen, very little data based on controlled randomized trials are available. In healthy middle-aged men, low dietary starch intake associated with increased levels of fibrinogen ${ }^{52}$, while reduction in dietary fat does not influence fibrinogen concentration $^{18,49,53}$.

\section{Fibrinolysis}

Elevated PAI-1 activity decreases fibrinolytic activity and increases the risk of coronary artery disease, venous thromboembolism and acute myocardial infarction ${ }^{54-56}$. Most of the present data on thrombogenic profile, particularly in overweight or obese persons, relate to PAI-1, the primary inhibitor of the fibrinolytic system. Obese and NIDDM subjects have significantly higher plasma PAI-1 than control subjects ${ }^{57}$, and waist/hip-ratio correlates strongly positively with coagulation factors and negatively with fibrinolytic factors in premenopausal women with abdominal obesity ${ }^{58}$. Older women receiving postmenopausal hormone therapy have more favourable plasma levels of PAI-1 and fibrinogen than non-users ${ }^{59}$.
It has been understood only very recently that adipose tissue has an active role in thrombogenesis ${ }^{60}$. Elevated plasma PAI-1 activity in the obese may be caused by increased PAI-1 release from visceral adipose tissue $^{61}$. Except for insulin ${ }^{62}$, at least two cytokines, tumour necrosis factor alpha (TNF- $\alpha$ ) and transforming growth factor beta (TGF- $\beta$ ), induce PAI-1 gene expression in the adipose tissue ${ }^{62,63}$. Although strenuous physical activity in young athletes increases acutely serum $\mathrm{TNF}-\alpha^{64}$, it is not known how regular exercise training modulates cytokines chronically or acutely in a response to a single bout of physical exercise.

Fibrinolytic response to acute physical activity depends on exercise intensity ${ }^{65}$. Increased plasma epinephrine during exercise is the primary stimulus for t-PA thereby reducing PAI-1 activity ${ }^{66}$. However, this exercise-induced increase in fibrinolytic activity is shortlived $^{65}$. There is also suggestive evidence that regular exercise training decreases PAI-1 level at least in sedentary young men ${ }^{15,67}$ and in elderly men ${ }^{46,68}$. Several preanalytical factors such as diurnal variation and difficulties in blood collection and handling have significant effects on fibrinolytic activity ${ }^{69,70}$, and these confounding factors make it essential to include a reference group in a study design.

The $4 \mathrm{G}$ allele of the $4 \mathrm{G} / 5 \mathrm{G}$ polymorphism in the PAI- 1 promoter gene associates with an increased PAI-1 level and higher risk of cardiovascular diseases ${ }^{71-73}$. Moreover, at least in diabetic patients ${ }^{73,74}$ and subjects who had suffered myocardial infarction ${ }^{75}$, homozygotes for the $4 \mathrm{G}$ allele are particularly sensitive for the increasing effect of hypertriglyceridaemia on PAI-1 level. Diet rich in monounsaturated fatty acids decreases plasma PAI-1 in young healthy males ${ }^{76}$, while in subjects with impaired glucose tolerance, fat-modified diet did not alter PAI- $1^{77}$. These observations raise the question whether the responses to physical activity or low fat diet in fibrinolysis vary between different $4 \mathrm{G} / 5 \mathrm{G}$ genotypes. We observed in a three-year controlled randomized exercise intervention in a population based sample of middle-aged men that the $4 \mathrm{G} / 4 \mathrm{G}$ subjects tend to have higher PAI-1 activity than other genotypes, but the $4 \mathrm{G} / 4 \mathrm{G}$ men were also more sensitive to a PAI-1 lowering effect of physical activity ${ }^{78}$. A change in waist circumference, although not identical to measurement of visceral fat, did not explain this finding.

\section{Interactions between physical activity and diet on haemostatic factors}

As reviewed above, both moderate physical activity and diet influence the individual's thrombogenic susceptibility in several ways. In the following we will consider only controlled randomized clinical trials, which respond to the current requirements for 
Table 2 Controlled randomized clinical trials of interactions between physical activity and fat modified diets on haemostatic factors

\begin{tabular}{|c|c|c|}
\hline Study design & Subjects (age, years) & Main results \\
\hline $\begin{array}{l}\text { A 14-week fish diet } \\
\text { and exercise } \\
\text { programme }^{79} \text {. }\end{array}$ & $\begin{array}{l}99 \text { healthy female } \\
\text { students (mean 22). }\end{array}$ & $\begin{array}{l}\text { Platelet aggregation, thromboxane } \mathrm{B}_{2} \text { and } \\
\text { prostacyclin unchanged. }\end{array}$ \\
\hline $\begin{array}{l}\text { A 6-month aerobic } \\
\text { exercise and/or fat } \\
\text { modified diet }^{18} \text {. }\end{array}$ & $\begin{array}{l}119 \text { normolipidaemic } \\
\text { men }(51-53) \text {. }\end{array}$ & $\begin{array}{l}\text { Modest decrease in saturated and/or } \\
\text { increase in unsaturated fat intake did not } \\
\text { modify FVIIc, FX activity, antithrombin III, } \\
\text { fibrinogen, t-PA antigen or PAI-1 antigen } \\
\text { either alone or in a combination with } \\
\text { exercise. }\end{array}$ \\
\hline $\begin{array}{l}\text { A } 12 \text {-week } 4200 \mathrm{~kJ} / \mathrm{d} \\
\text { diet and/or moderate } \\
\text { exercise }^{49} \text {. }\end{array}$ & $\begin{array}{l}121 \text { overweight } \\
\text { women }(54 \pm 3)\end{array}$ & $\begin{array}{l}\text { Diet decreased PAl-1 activity and antigen, } \\
\text { and t-PA antigen with no additional effect of } \\
\text { physical activity. No effect on fibrinogen. }\end{array}$ \\
\hline $\begin{array}{l}\text { A 8-week moderate } \\
\text { aerobic exercise and } \\
\text { a low-fat diet with } \\
\text { one daily fish meal }{ }^{80} \text {. }\end{array}$ & $\begin{array}{l}55 \text { sedentary type } 2 \\
\text { diabetics with serum } \\
\text { triglycerides }>1.8 \mathrm{mmol} / \mathrm{l} \\
\text { and/or HDL-C } \\
<1.0 \mathrm{mmol} / \mathrm{l} \text { (mean } 53 \text { ). }\end{array}$ & $\begin{array}{l}\text { The fish diet and exercise as well as } \\
\text { combined diet and exercise reduced t-PA } \\
\text { antigen. The fish diet alone increased FVIlc, } \\
\text { which was prevented by exercise. No effects } \\
\text { on PAI-1 antigen or fibrinogen. }\end{array}$ \\
\hline
\end{tabular}

evidence based data in health sciences. Only four studies have dealt with diet and physical activity simultaneously with regard to changes in selected haemostatic factors as the outcome measure (Table 2). Such studies are very demanding (costs, study protocol, laboratory analyses etc.) to accomplish, particularly for any longer period of time. Sample size, compliance and adherence are the key issues, which determine whether the study will have power enough to detect the changes due to the intervention.

\section{Controlled randomized clinical trials}

Both physical activity and diet are natural components of human everyday life and therefore their impacts should be investigated together. Based on the review of the literature, one can expect to achieve a larger impact on the various outcome variables (blood lipids, coagulation and fibrinolytic factors) with simultaneous changes in habitual physical activity and diet. However, it may as well be the case that when two life-style interventions are combined, neither will work optimally. The functional nature of the haemostatic system is characterized by its rapid activation and inactivation and may well explain much of the controversies in the literature.

A 14-week exercise and fish diet intervention in a large group of young healthy females failed to induce any changes in platelet function and prostaglandins ${ }^{79}$. In the diet and combined diet and exercise groups, proportion of omega-3 fatty acid increased in the platelets and erythrocytes suggesting compliance with diet. In contrast, the actual increase of exercise was only 1.3 times a week with no change in maximal oxygen uptake in the exercise groups indicating less than prescribed physical activity. Although the modest compliance with the intervention may explain to some extent the lack of changes in outcome variables, one should keep in mind that the subjects were young, healthy girls with normal body weight.

In a controlled randomized clinical trial in men for six months ${ }^{18}$, we could not see any differences between reference and experimental groups in any coagulation or fibrinolytic parameters. The compliance of our clinically healthy subjects was good, the sample size was large and the age range was narrow (51 to 53 years). To avoid measuring the acute effects of exercise, blood samples were drawn one week after stopping the exercise programme. Our data indicate that the responses of thrombogenic and fibrinolytic parameters to aerobic exercise, if any, are a temporary phenomenon. Modest changes in dietary fat intake did not seem to have any influence on the haemostatic factors.

In a large group of overweight postmenopausal women, low energy diet (1000 kcal/d) decreased PAI-1 activity and antigen as well as t-PA antigen ${ }^{49}$. Moderate intensity aerobic and resistance weight training did not induce any additional effect on PAI-1 or t-PA. Neither diet alone nor with exercise affected plasma fibrinogen. The main emphasis of the study was in the dietary energy restriction resulting in a substantial loss of fat tissue mass, while the exercise programme was modest with only three weekly exercise sessions.

In another recent fish diet and moderate aerobic exercise trial in dyslipidaemic type 2 diabetics $^{80}$, t-PA antigen concentration decreased in moderate exercise, diet and combined exercise and diet groups, while PAI1 antigen and fibrinogen remained unchanged. Fish diet alone increased FVIIc, while concomitantly taken aerobic exercise prevented the elevation. The evaluation of the study results is hampered by the fact that the authors give no data on changes in diet (especially fat intake) or changes in physical activity or fitness. 


\section{Key issues}

There have been several short-comings in many studies investigating the impact of changes in physical activity patterns or in dietary habits in relations to blood coagulation and fibrinolysis. Generally, the requirement for adequate statistical power needs to be emphasized. Since haemostatic factors are characterized by high intraindividual variability, only with large enough sample size can one avoid false conclusions in clinical intervention trials. In order to find cause and effect relationships, only controlled randomized clinical trials represent appropriate study design. Using a representative sample of the study population as subjects, the results may be generalizable and thereby useful in the clinical practice for the prevention of thrombogenic sequelae and complications.

\section{References}

1 Ross R. Atherosclerosis - an inflammatory disease. N. Engl.J. Med. 1999; 340: 115-26.

2 Hassouna HI. Laboratory evaluation of hemostatic disorders. Hematol. Oncol. Clin. North Am. 1993; 7: 1161-249.

3 Kazal LA. Coagulation chemistry. In: Spiegel HE, ed. Clinical Biochemistry. Comtemporary theories and techniques.(2), 73-143. 1982. New York, Academic Press, Inc.

4 Lefkovits J, Plow EF, Topol EJ. Platelet glycoprotein IIb/IIIa receptors in cardiovascular medicine. N. Engl. J. Med. 1995; 332: $1553-59$

5 Lijnen HR, Collen D. Mechanisms of physiological fibrinolysis. Baillieres Clin. Haematol. 1995; 8: 277-90.

6 Booth NA, Bennett B. Fibrinolysis and thrombosis. Baillieres Clin. Haematol. 1994; 7: 559-72.

7 Tofler GH, Brezinski D, Schafer AI, Czeisler CA, Rutherford JD, Willich SN, Gleason RE, Williams GH, Muller JE. Concurrent morning increase in platelet aggregability and the risk of myocardial infarction and sudden cardiac death. $N$. Engl. J. Med. 1987; 316: 1514-18.

8 Rauramaa R, Salonen JT, Seppänen K, Salonen R, Venäläinen JM, Ihanainen M, Rissanen V. Inhibition of platelet aggregability by moderate-intensity physical exercise: a randomized clinical trial in overweight men. Circulation 1986; 74 : 939-44.

9 Wang JS, Jen CJ, Chen HI. Effects of exercise training and deconditioning on platelet function in men. Arterioscler Thromb. Vasc. Biol. 1995; 15: 1668-74.

10 Wang JS, Jen CJ, Chen HI. Effects of chronic exercise and deconditioning on platelet function in women. J. Appl. Physiol. 1997; 83: 2080-5.

11 Rauramaa R, Salonen JT, Kukkonen-Harjula K, Seppänen K, Seppälä E, Vapaatalo H, Huttunen JK. Effects of mild physical exercise on serum lipoproteins and metabolites of arachidonic acid: a controlled randomised trial in middle aged men. Br. Med. J. (Clin. Res. Ed.) 1984; 288: 603-6.

12 Thorngren M, Gustafson A. Effects of 11-week increases in dietary eicosapentaenoic acid on bleeding time, lipids, and platelet aggregation. Lancet 1981; 2: 1190-3.

13 Mori TA, Beilin LJ, Burke V, Morris J, Ritchie J. Interactions between dietary fat, fish, and fish oils and their effects on platelet function in men at risk of cardiovascular disease. Arterioscler. Thromb. Vasc. Biol. 1997; 17: 279-86.

14 Meade TW, Mellows S, Brozovic M, Miller GJ, Chakrabarti RR, North WR, Haines AP, Stirling Y, Imeson JD, Thompson SG. Haemostatic function and ischaemic heart disease: principal results of the Northwick Park Heart Study. Lancet 1986; 2: 533-7.

15 Gris JC, Schved JF, Feugeas O, Aguilar-Martinez P, Arnaud A, Sanchez N, Sarlat C. Impact of smoking, physical training and weight reduction on FVII, PAI-1 and hemostatic markers in sedentary men. Thromb. Haemost. 1990; 64: 516-20.

16 Connelly JB, Cooper JA, Meade TW. Strenuous exercise, plasma fibrinogen, and factor VII activity. Br. Heart J. 1992; 67: 351-4.

17 van den Burg PJ, Hospers JE, van Vliet M, Mosterd WL, Huisveld IA. Unbalanced haemostatic changes following strenuous physical exercise. A study in young sedentary males. Eur. Heart J. 1995; 16: 1995-2001.

18 Rankinen T, Rauramaa R, Väisänen S, Halonen P, Penttilä I. Blood coagulation and fibrinolytic factors are unchanged by aerobic exercise or fat modified diet. Fibrinolysis 1994; 8 $48-53$.

19 Miller GJ, Martin JC, Webster J, Wilkes H, Miller NE, Wilkinson WH, Meade TW. Association between dietary fat intake and plasma factor VII coagulant activity - a predictor of cardiovascular mortality. Atherosclerosis 1986; 60: 269-77.

20 Miller GJ, Cruickshank JK, Ellis LJ, Thompson RL, Wilkes HC, Stirling Y, Mitropoulos KA, Allison JV, Fox TE, Walker AO Fat consumption and factor VII coagulant activity in middleaged men. An association between a dietary and thrombogenic coronary risk factor. Atherosclerosis 1989; 78: 19-24.

21 Miller GJ, Martin JC, Mitropoulos KA, Reeves BE, Thompson RL, Meade TW, Cooper JA, Cruickshank JK. Plasma factor VII is activated by postprandial triglyceridaemia, irrespective of dietary fat composition. Atherosclerosis 1991; 86: 163-71.

22 Connelly JB, Roderick PJ, Cooper JA, Meade TW, Miller GJ. Positive association between self-reported fatty food consumption and factor VII coagulant activity, a risk factor for coronary heart disease, in 4246 middle-aged men. Thromb. Haemost. 1993; 70: 250-2.

23 Marckmann P, Sandström B, Jespersen J. Dietary effects on circadian fluctuation in human blood coagulation factor VII and fibrinolysis. Atherosclerosis 1993; 101: 225-34.

24 Salomaa V, Rasi V, Pekkanen J, Jauhiainen M, Vahtera E, Pietinen P, Korhonen H, Kuulasmaa K, Ehnholm C. The effects of saturated fat and n-6 polyunsaturated fat on postprandial lipemia and hemostatic activity. Atherosclerosis 1993; 103: 1-11

25 Bladbjerg EM, Tholstrup T, Marckmann P, Sandström B, Jespersen J. Dietary changes in fasting levels of factor VII coagulant activity (FVII: C) are accompanied by changes in factor VII protein and other vitamin K-dependent proteins. Thromb. Haemost. 1995; 73: 239-42.

26 Negri M, Arigliano PL, Talamini G, Carlini S, Manzato F, Bonadonna G. Levels of plasma factor VII and factor VII activated forms as a function of plasma triglyceride levels. Atherosclerosis 1993; 99: 55-61.

27 Silveira A, Karpe F, Blombäck M, Steiner G, Walldius G, Hamsten A. Activation of coagulation factor VII during alimentary lipemia. Arterioscler. Thromb. 1994; 14: 60-9.

28 Väisänen S, Rankinen T, Penttilä I, Rauramaa R. Factor VII coagulant activity in relation to serum lipoproteins and dietary fat in middle-aged men. Thromb. Haemost. 1995; 73: 435-8.

29 Marckmann P, Sandström B, Jespersen J. Effects of total fat content and fatty acid composition in diet on factor VII coagulant activity and blood lipids. Atherosclerosis 1990; 80: 227-33.

30 Marckmann P, Sandström B, Jespersen J. Favorable longterm effect of a low-fat/high-fiber diet on human blood coagulation and fibrinolysis. Arterioscler. Thromb. 1993; 13: 505-11.

31 Marckmann P, Sandström B, Jespersen J. Fasting blood coagulation and fibrinolysis of young adults unchanged by 
reduction in dietary fat content. Arterioscler. Thromb. 1992; 12: $201-5$.

32 Mitropoulos KA, Miller GJ, Martin JC, Reeves BE, Cooper J. Dietary fat induces changes in factor VII coagulant activity through effects on plasma free stearic acid concentration. Arterioscler. Thromb. 1994; 14: 214-22.

33 Hoffman CJ, Miller RH, Hultin MB. Correlation of factor VII activity and antigen with cholesterol and triglycerides in healthy young adults. Arterioscler. Thromb. 1992; 12: 26770.

34 Marckmann P, Sandström B, Jespersen J. Low-fat, high-fiber diet favorably affects several independent risk markers of ischemic heart disease: observations on blood lipids, coagulation, and fibrinolysis from a trial of middle-aged Danes. Am.J. Clin. Nutr. 1994; 59: 935-9.

35 Bruckert E, Carvalho dS, Giral P, Soria C, Chapman MJ, Caen $\mathrm{J}$, de Gennes JL. Interrelationship of plasma triglyceride and coagulant factor VII levels in normotriglyceridemic hypercholesterolemia. Atherosclerosis 1989; 75: 129-34.

36 Mitropoulos KA, Miller GJ, Watts GF, Durrington PN. Lipolysis of triglyceride-rich lipoproteins activates coagulant factor XII: a study in familial lipoprotein-lipase deficiency. Atherosclerosis 1992; 95: 119-25.

37 Green F, Kelleher C, Wilkes H, Temple A, Meade T, Humphries S. A common genetic polymorphism associated with lower coagulation factor VII levels in healthy individuals. Arterioscler. Thromb. 1991; 11: 540-6.

38 Humphries SE, Lane A, Green FR, Cooper J, Miller GJ. Factor VII coagulant activity and antigen levels in healthy men are determined by interaction between factor VII genotype and plasma triglyceride concentration. Arterioscler. Thromb. 1994; 14: 193-8.

39 Saha N, Liu Y, Heng CK, Hong S, Low PS, Tay JS. Association of factor VII genotype with plasma factor VII activity and antigen levels in healthy Indian adults and interaction with triglycerides. Arterioscler. Thromb. 1994; 14: 1923-7.

40 Bernardi F, Marchetti G, Pinotti M, Arcieri P, Baroncini C, Papacchini M, Zepponi E, Ursicino N, Chiarotti F, Mariani G. Factor VII gene polymorphisms contribute about one third of the factor VII level variation in plasma. Arterioscler. Thromb. Vasc. Biol. 1996; 16: 72-6.

41 Silveira A, Green F, Karpe F, Blombäck M, Humphries S, Hamsten A. Elevated levels of factor VII activity in the postprandial state: effect of the factor VII Arg-Gln polymorphism. Thromb. Haemost. 1994; 72: 734-9.

42 Pankow JS, Folsom AR, Shahar E, Tsai MY, Jeffery RW, Wing RR. Weight-loss induced changes in plasma factor VII coagulant activity and relation to the factor VII Arg/Gln353 polymorphism in moderately obese adults. Thromb. Haemost. 1998; 79: 784-9.

43 Benderly M, Graff E, Reicher-Reiss H, Behar S, Brunner D, Goldbourt U. Fibrinogen is a predictor of mortality in coronary heart disease patients. The Bezafibrate Infarction Prevention (BIP) Study Group. Arterioscler. Thromb. Vasc. Biol. 1996; 16: 351-6.

44 Thompson SG, Kienast J, Pyke SD, Haverkate F, van de Loo JC. Hemostatic factors and the risk of myocardial infarction or sudden death in patients with angina pectoris. European Concerted Action on Thrombosis and Disabilities Angina Pectoris Study Group. N. Engl. J. Med. 1995; 332: 635-41.

45 Väisänen S. Associations of physical activity, fibrinogen genotypes and blood lipoproteins with thrombogenic factors in humans. Kuopio University Publications D. Medical Sciences 131. Doctoral Dissertation. 1997. Kuopio University, Kuopio, Finland.

46 Stratton JR, Chandler WL, Schwartz RS, Cerqueira MD, Levy WC, Kahn SE, Larson VG, Cain KC, Beard JC, Abrass IB. Effects of physical conditioning on fibrinolytic variables and fibrinogen in young and old healthy adults. Circulation 1991; 83: 1692-7.
47 Vanninen E, Laitinen J, Uusitupa M. Physical activity and fibrinogen concentration in newly diagnosed NIDDM. Diabetes Care 1994; 17: 1031-8.

48 Montgomery HE, Clarkson P, Nwose OM, Mikailidis DP, Jagroop IA, Dollery C, Moult J, Benhizia F, Deanfield J, Jubb M, World M, McEwan JR, Winder A, Humphries S. The acute rise in plasma fibrinogen concentration with exercise is influenced by the G-453-A polymorphism of the betafibrinogen gene. Arterioscler. Thromb. Vasc. Biol. 1996; 16: 386-91.

49 Svendsen OL, Hassager C, Christiansen C, Nielsen JD, Winther K. Plasminogen activator inhibitor-1, tissue-type plasminogen activator, and fibrinogen: Effect of dieting with or without exercise in overweight postmenopausal women. Arterioscler. Thromb. Vasc. Biol. 1996; 16: 381-5.

50 Schuit AJ, Schouten EG, Kluft C, de Maat M, Menheere PP, Kok FJ. Effect of strenuous exercise on fibrinogen and fibrinolysis in healthy elderly men and women. Thromb. Haemost. 1997; 78: 845-51.

51 Rauramaa R, Väisänen S, Nissinen A, Rankinen T, Penttilä I, Saarikoski S, Tuomilehto J, Gagnon J, Perusse L, Bouchard C. Physical activity, fibrinogen plasma level and gene polymorphisms in postmenopausal women. Thromb. Haemost. 1997; 78: 840-4.

52 Rauramaa R, Väisänen S, Penttilä I, Rankinen T. Inverse relationship between dietary starch intake and plasma fibrinogen in middle-aged men. Nut. Metab. Cardiovasc. Dis. 1994; 4: 192-6.

53 Miller GJ. Effects of diet composition on coagulation pathways. Am. J. Clin. Nutr. 1998; 67: 542S-5S.

54 Hamsten A, de Faire U, Walldius G, Dahlen G, Szamosi A, Landou C, Blombäck M, Wiman B. Plasminogen activator inhibitor in plasma: risk factor for recurrent myocardial infarction. Lancet 1987; 2: 3-9.

55 Juhan-Vague I, Pyke SD, Alessi MC, Jespersen J, Haverkate F, Thompson SG. Fibrinolytic factors and the risk of myocardial infarction or sudden death in patients with angina pectoris. ECAT Study Group. European Concerted Action on Thrombosis and Disabilities. Circulation 1996; 94: 2057-63.

56 Salomaa V, Stinson V, Kark JD, Folsom AR, Davis CE, Wu KK. Association of fibrinolytic parameters with early atherosclerosis. The ARIC Study. Atherosclerosis Risk in Communities Study. Circulation 1995; 91: 284-90.

57 McGill JB, Schneider DJ, Arfken CL, Lucore CL, Sobel BE. Factors responsible for impaired fibrinolysis in obese subjects and NIDDM patients. Diabetes 1994; 43: 104-9.

58 Avellone G, Di Garbo V, Cordova R, Raneli G, De Simone R, Bompiani G. Coagulation, fibrinolysis and haemorheology in premenopausal obese women with different body fat distribution. Thromb. Res. 1994; 75: 223-31.

59 Meilahn EN, Cauley JA, Tracy RP, Macy EO, Gutai JP, Kuller LH. Association of sex hormones and adiposity with plasma levels of fibrinogen and PAI-1 in postmenopausal women. Am. J. Epidemiol. 1996; 143: 159-66.

60 Samad F, Loskutoff DJ. The fat mouse: a powerful genetic model to study elevated plasminogen activator inhibitor 1 in obesity/NIDDM. Thromb. Haemost. 1997; 78: 652-5.

61 Lundgren CH, Brown SL, Nordt TK, Sobel BE, Fujii S. Elaboration of type-1 plasminogen activator inhibitor from adipocytes. A potential pathogenetic link between obesity and cardiovascular disease. Circulation 1996; 93: 106-10.

62 Samad F, Loskutoff DJ. Tissue distribution and regulation of plasminogen activator inhibitor-1 in obese mice. Mol. Med. 1996; 2: 568-82.

63 Samad F, Yamamoto K, Pandey M, Loskutoff DJ. Elevated expression of transforming growth factor-beta in adipose tissue from obese mice. Mol. Med. 1997; 3: 37-48.

64 Weinstock C, König D, Harnischmacher R, Keul J, Berg A, Northoff $H$. Effect of exhaustive exercise stress on the cytokine response. Med. Sci. Sports Exerc. 1997; 29: 345-54. 
65 Rankinen T, Väisänen S, Penttilä I, Rauramaa R. Acute dynamic exercise increases fibrinolytic activity. Thromb. Haemost. 1995; 73: 281-6.

66 Chandler WL, Levy WC, Stratton JR. The circulatory regulation of TPA and UPA secretion, clearance, and inhibition during exercise and during the infusion of isoproterenol and phenylephrine. Circulation 1995; 92: 2984-94.

67 van den Burg PJ, Hospers JE, van Vliet M, Mosterd WL, Bouma BN, Huisveld IA. Effect of endurance training and seasonal fluctuation on coagulation and fibrinolysis in young sedentary men. J. Appl. Physiol. 1997; 82: 613-20.

68 Chandler WL, Schwartz RS, Stratton JR, Vitiello MV. Effects of endurance training on the circadian rhythm of fibrinolysis in men and women. Med. Sci. Sports Exerc. 1996; 28: 647-55.

69 Juhan-Vague I, Alessi MC, Raccah D, Aillaud MF, Billerey M, Ansaldi J, Philip-Joet C, Vague P. Daytime fluctuations of plasminogen activator inhibitor 1 (PAI-1) in populations with high PAI-1 levels. Thromb. Haemost. 1992; 67: 76-82.

70 Kluft C, Verheijen JH. Leiden fibrinolysis working party: blood collection and handling procedures for assessment of tissuetype plasminogen activator (t-PA) and plasminogen activator inhibitor-1 (PAI-1). Fibrinolysis 1990; 4(suppl. 2): 155-61.

71 Eriksson P, Kallin B, van't Hooft FM, Båvenholm P, Hamsten A. Allele-specific increase in basal transcription of the plasminogen-activator inhibitor 1 gene is associated with myocardial infarction. Proc. Natl. Acad. Sci. USA 1995; 92 : 1851-5.

72 Margaglione M, Cappucci G, Colaizzo D, Giuliani N, Vecchione G, Grandone E, Pennelli O, Di Minno G. The PAI-1 gene locus $4 \mathrm{G} / 5 \mathrm{G}$ polymorphism is associated with a family history of coronary artery disease. Arterioscler. Thromb. Vasc. Biol. 1998; 18: 152-6.

73 Panahloo A, Mohamed-Ali V, Lane A, Green F, Humphries SE, Yudkin JS. Determinants of plasminogen activator inhibitor 1 activity in treated NIDDM and its relation to a polymorphism in the plasminogen activator inhibitor 1 gene. Diabetes 1995; 44: 37-42.
74 Mansfield MW, Stickland MH, Grant PJ. Environmental and genetic factors in relation to elevated circulating levels of plasminogen activator inhibitor-1 in Caucasian patients with non-insulin-dependent diabetes mellitus. Thromb. Haemost. 1995; 74: 842-7.

75 Ossei-Gerning N, Mansfield MW, Stickland MH, Wilson IJ Grant PJ. Plasminogen activator inhibitor-1 promoter $4 \mathrm{G} / 5 \mathrm{G}$ genotype and plasma levels in relation to a history of myocardial infarction in patients characterized by coronary angiography. Arterioscler Thromb. Vasc. Biol. 1997; 17: $33-7$.

76 Lopez-Segura F, Velasco F, Lopez-Miranda J, Castro P, LopezPedrera R, Blanco A, Jimenez-Pereperez J, Torres A, Trujillo J, Ordovas JM, Pérez-Jiménez F. Monounsaturated fatty acidenriched diet decreases plasma plasminogen activator inhibitor type 1. Arterioscler. Thromb. Vasc. Biol. 1996; 16: $82-8$.

77 Niskanen L, Schwab US, Sarkkinen ES, Krusius T, Vahtera E, Uusitupa MI. Effects of dietary fat modification on fibrinogen, factor VII, and plasminogen activator inhibitor-1 activity in subjects with impaired glucose tolerance. Metabolism 1997; 46: 666-72.

78 Väisänen SB, Humphries SE, Luong LA, Penttilä I, Bouchard C, Rauramaa R. Regular Exercise, Plasminogen Activator Inhibitor-1 (PAI-1) Activity and the 4G/5G Promoter Polymorphism in the PAI-1 Gene. Thromb. Haemost. 1999, in press.

79 Agren JJ, Pekkarinen H, Litmanen H, Hänninen O. Fish diet and physical fitness in relation to membrane and serum lipids, prostanoid metabolism and platelet aggregation in female students. Eur. J. Appl. Physiol. 1991; 63: 393-8.

80 Dunstan DW, Mori TA, Puddey IB, Beilin LJ, Burke V, Morton AR, Stanton KG. A randomised, controlled study of the effects of aerobic exercise and dietary fish on coagulation and fibrinolytic factors in type 2 diabetics. Thromb. Haemost. 1999; 81: 367-72. 